\title{
LANDASAN SOSIAL BUDAYA DAN PERKEMBANGAN ILMU PENGETAHUAN DALAIM PENGEIMBANGAN KURIKULUMI
}

\author{
Rosni
}

Guru MAN Marioriawa Kabupaten Soppeng

\begin{abstract}
Education basically interacts educative interaction between educator and learner. The purpose of these educational interactions to realize the aspects of the curriculum that apply leads to the achievement of educational goals that have been formulated. Educational interactions are also strongly influenced by the environment, where educational activities occur. The same is said by Oliva in his book Developing the Curriculum, that the Curriculum is an educational tool that directly represents education in addressing community challenges. Community challenges can be categorized in various levels such as national, local, and nearby (regional). These challenges are not arrise just but reconstructed by a group of people and generally legalized by decision makers. Then the curriculum can be considered as the heart of education. That is, educational activities between educators and learners is strongly influenced by the contents that exist in the krikulum. So that in the absence of curriculum as if educational activity is not possible.
\end{abstract}

Keywords: Curriculum, Social, Culture and Science

\section{PENDAHULUAN}

$D$ endidikan mempunyai peran yang sangat penting bagi manusia. Pendidikan sebagai sarana untuk mengembangan potensi diri yang ada. Salah satu komponen penting dari sistem pendidikan tersebut adalah kurikulum, karena kurikulum merupakan komponen pendidikan yang dijadikan acuan oleh setiap satuan pendidikan, baik oleh pengelola maupun penyelenggara, khususnya oleh guru dan kepala sekolah. ${ }^{1}$ Kurikulum mempunyai kedudukan sentral dalam seluruh proses pendidikan. Kurikulum memberikan arahan segala bentuk aktivitas pendidikan demi tercapainya tujuan-tujuan pendidikan. Kurikulum juga merupakan suatu rencana pendidikan memberikan pedoman dan pegangan tentang jenis, lingkup, dan urutan isi, serta proses pendidikan.

Kurikulum sebagai rancangan pendidikan memiliki kedudukan yang sangat sentral dalam seluruh kegiatan pembelajaran, yang menentukan proses dan hasil belajar. Sedangkan Pengembangan kurikulum dilakukan untuk mewujudkan adanya nilai tambah dari yang telah dilakukan sesuai denga kurikulum potensial sesuai dengan

\footnotetext{
${ }^{1}$ Nana Syaodih Sukmadinata, Pengembangan Kurikulum Teori dan Praktek (Bandung: Remaja Rosdakarya, 2001), h. 4.
} 
tujuan pendidikan. Oleh karena itu, pemahaman tentang kurikulum bagi para tenaga pendidik mutlak diperlukan.

Kurikulum akan selalu berkembang agar dapat memenuhi kebutuhan suatu lembaga. Ketika kurikulum tidak dikembangkan sesuai dengan meningkatnya kebutuhan suatu lembaga, maka lembaga itu akan mengalami ketertinggalan. Penyusunan kurikulum membutuhkan landasan-landasan yang kuat, yang didasarkan oleh hasil-hasil pemikiran dan penelitian yang mendalam dan sesuai dengan tantangan zaman. Karena kurikulum ibarat sebuah rumah yang harus mempunyai pondasi agar dapat berdiri tegak, tidak rubuh dan dapat memberikan kenyamanan bagi yang tinggal di dalamnya, pondasi tersebut ialah landasan-landasan untuk kuriulum sebagai rumahnya, agar bisa memberikan kenyamanan dan kemudahan bagi peserta didik untuk menuntut ilmu dan menjadikannya produk yang berguna bagi dirinya sendiri, agama, masyarakat dan negaranya. Bila landasan rumahnya lemah, maka yang ambruk adalah rumahnya sedangkan jika landasan kurikulum yang lemah dalam pendidikan maka yang ambruk adalah manusianya. ${ }^{2}$

Kurikulum dalam pendidikan perlu mempunyai perhatian yang besar baik bagi pemerintah sebagai penanggung jawab umum atau pihak sekolah yang turun langsung mengimplementasikan kurikulum tersebut ke peserta didik,

\section{A. Landasan sosial budaya dan perkembangan ilmu pengetahuan dalam pengembangan kurikulum}

Kurikulum dapat dipandang sebagai suatu rancangan pendidikan. Sebagai suatu rancangan, kurikulum menentukan pelaksanaan dan hasil pendidikan. Pendidikan merupakan usaha mempersiapkan peserta didik untuk terjun ke lingkungan masyarakat. Pendidikan bukan hanya untuk pendidikan semata, namun memberikan bekal pengetahuan, keterampilan serta nilai-nilai untuk hidup, bekerja dan mencapai perkembangan lebih lanjut di masyarakat. Peserta didik berasal dari masyarakat, mendapatkan pendidikan baik formal maupun informal dalam lingkungan masyarakat dan diarahkan bagi kehidupan masyarakat pula.

Kehidupan masyarakat, dengan segala karakteristik dan kekayaan budayanya menjadi landasan dan sekaligus acuan bagi pendidikan. Melalui pendidikan, kita mengharapkan melalui pendidikan dapat lebih mengerti dan mampu membangun kehidupan masyakatnya. Maka dari itu, tujuan, isi, maupun proses pendidikan harus disesuaikan dengan kebutuhan, kondisi, karakteristik, kekayaan dan perkembangan yang ada di masyakarakat. Karena setiap lingkungan masyarakat masing-masing memiliki sistem-sosial budaya tersendiri yang mengatur pola kehidupan dan pola hubungan antar anggota masyarakat.

Ada dua pertimbangan sosial budaya yang dijadikan landasan dalam pengembangan kurikulum: pertama,Setiap orang dalam masyarakat selalu berhadapan

\footnotetext{
${ }^{2}$ Nana Syaodih Sukmadinata, Pengembangan Kurikulum Teori dan Praktek, h. 6
} 
dengan masalah anggota masyarakat yang belum dewasa dalam kebudayaan. Maksunya manusia belum mampu menyesuaikan dengan cara kelompoknya. Kedua, Kurikulum dalam setiap masyarakat merupakan refleksi dari cara orang perfikir, berasa, bercita-cita atau kebiasaan. Karena itu untuk membina struktur dan fungsi kurikulum, perlu memahami kebudayaan. ${ }^{3}$

Karena itu, para pengembang kurikulum harus:

1. Mempelajari dan memahami kebutuhan masyarakat.

2. Menganalisis budaya masyarakat tempat sekolah berada.

3. Menganalisis kekuatan serta potensi daerah.

4. Menganalisis syarat dan tuntunan tenaga kerja.

5. Menginterpretasi kebutuhan individu dalam kerangka kepentingan masyarakat. ${ }^{4}$

Dari penjelasan tersebut dapat diungkapkan bahwa melalui pendidikan manusia mengenal peradaban masa lalu, turut serta dalam peradaban sekarang dan membuat peradaban masa yang akan datang. Penerapan teori, prinsip, hukum, dan konsep-konsep yang terdapat dalam semuailmu pengetahuan yang ada dalam kurikulum, harus disesuaikan dengan kondisi sosial budaya masyarakat setempat, sehingga hasil belajar yang dicapai oleh siswa lebih bermakna dalam hidupnya.Pengembangan kurikulum hendaknya memperhatikan kebutuhan masyarakat dan perkembangan masyarakat. Disinilah tuntutan masyarakat adalah salah satu dasar dalam pengembangan kurikulum. Tujuh fungsi sosial pendidikan, yaitu:

1. Mengajar keterampilan,

2. Mentransmisikan budaya,

3. Mendorong adaptasi lingkungan,

4. Membentuk kedisiplinan,

5. Mendorong bekerja berkelompok,

6. Meningkatkan perilaku etik, dan

7. Memilih bakat dan memberi penghargaan prestasi. ${ }^{5}$

Faktor kebudayaaan merupakan bagian yang penting dalam pengembangan kurikulum, antara lain:

1. Individu lahir tidak berbudaya, baik dalam hal kebiasaan, cita-cita, sikap, pengetahuan, keterampilan dan sebagainya. Semua itu dapat diperoleh individu melalui interaksi dengan lingkungan, budaya, keluarga, masyarakat sekitar, dan sekolah/lembaga pendidikan. Oleh karena itu, sekolah/lembaga pendidikan mempunyai tugas khusus untuk memberikan pengalaman kepada para peserta didik

${ }^{3}$ Abdullah Idi , Pengembangan Kurikulum, teori \& praktek (Cet.1; Yogyakarta, arr ruzz media, 2007), h. 77

${ }^{4}$ Abdullah Idi , Pengembangan Kurikulum, teori \& praktek, h. 77.

${ }^{5}$ Ngalim Purwanto, Ilmu Pendidikan, Teoritis dan praktis (Cet 3; Bandung;Rosdakarya, 2008),h. $18-23$ 
dengan salah satu alat yang disebut kurikulum.

2. Kurikulum pada dasarnya mengakomodasi aspek-aspek sosial dan budaya. Aspek sosiologis adalah yang berkenaan dengan kondisi sosial masyarakat yang sangat beragam, seperti masyarakat industry, pertanian, nelayan, dan sebagainya. Pendidikan seolah pada dasarnya bertujuan mendidik anggota masyarakat agar dapat hidup berintegrasi dan beradaptasi dengan anggota masyarakat lainnya serta meningkatkan kualitas hidupnya sebagai makhluk berbuadaya. Hal ini membawa implikasi bahwa kurikulum sebagai salah satu alat untuk mencapai tujuan pendidikan bermuatan kebudayaan yang bersifat umum seperti: nilai-nilai, sikapsikap, pengetahuan, dan kecakapan. ${ }^{6}$

Mengingat begitu pentingnya pengembangan kurikulum demi kemajuan pembangunan kualitas sumber daya manusia maka sangatlah penting bagi seorang akadmisi memahami bagaimana kurikulum itu harus dikembangkan. Kurikulum baik pada tahap kurikulum sebagai ide, rencana, pengalaman maupun kurikulum sebagai hasil dalam pengembangannya harus mengacu atau menggunakan landasan yang kuat dan kokoh, agar kurikulum tersebut dapat berfungsi serta berperan sesuai dengan tuntutan pendidikan yang ingin dihasilkan seperti tercantum dalam rumusan tujuan pendidikan nasional yang telah digariskan dalam UU no. 20 tahun 2003.

\section{B. Komponen dan Kedudukan Kurikulum dalam Pendidikan}

\section{Komponen Kurikulum}

Kurikulum dapat diuraikan secara struktural, yang memuat setidak-tidaknya empat komponen penting yang saling berkaitan satu sama lain. Hasan Langgulung menguraikan keempat komponen kurikulum tersebut dengan rinci, yaitu:

a. Tujuan-tujuan yang ingin dicapai oleh suatu pendidikan. Secara eksplisit yang ingin dicapai adalah orang yang bagaimana yang akan dibentuk dengan kurikulum tersebut.

b. Knowledge (pengetahuan), informasi-informasi, data-data, aktivitas-aktivitas dan pengalaman-pengalaman yang menjadikan kurikulum itu terbentuk. Yang kedua ini semakna dengan mata pelajaran.

c. Metode dan cara-cara mengajar yang dipakai oleh guru-guru untuk mengajar dan memotivasi peserta didik untuk mengarahkan mereka ke arah yang dikehendaki oleh kurikulum.

d. Metode dan cara penilaian yang digunakan dalam mengukur dan menilai kurikulum dan hasil proses pendidikan yang direncanakan kurikulum tersebut. ${ }^{7}$

Sedangkan S. Nasution memaparkan empat komponen tersebut yang didasarkan pada empat pertanyaan penting yang dilontarkan oleh W. Tyler, yaitu:

\footnotetext{
${ }^{6}$ Ngalim Purwanto, Ilmu Pendidikan, Teoritis dan praktis, h. 18-23.

${ }^{7}$ Hasan Langgulung, Asas-Asas Pendidikan Islam (Cet. XVII; Jakarta: Pustaka Al-Husna, 2010), h. 303
} 
a. Tujuan apa yang harus dicapai sekolah?

b. Bagaimana memilih bahan pelajaran guna mencapai tujuan itu?

c. Bagaimana bahan disajikan agar efektif diajarkan?

d. Bagaimana efektivitas belajar dapat dinilai?. ${ }^{8}$

\section{Kedudukan Kurikulum Dalam Pendidikan}

Kurikulum merupakan unsur penting pada setiap lembaga pendidikan. Secara fisik, kurikulum dapat berbentuk suatu dokumen berisikan berbagai komponen seperti pikiran tentang pendidikan, tujuan yang akan dicapai oleh kurikulum tersebut, konten yang dirancang dan harus dikuasai peserta didik untuk menguasai tujuan, proses yang dirancang untuk menguasai konten, evaluasi yang dirancang untuk mengetahui penguasaan kemampuan yang dinyatakan dalam tujuan, serta komponen lainnya.

Secara fisik, kurikulum dapat juga berbentuk proses pembelajaran yang dilakukan peserta didik dan guru di sekolah sehingga dapat diamati baik secara langsung maupun melalui alat perekam tertentu. Pada dasarnya, kurikulum merupakan jantung suatu proses pendidikan. ${ }^{9}$ Yakni, berkenaan dengan unsur-unsur fisik yang terlibat dalam proses pendidikan dan unsur-unsur non fisik seperti proses berfikir, proses penyimpanan informasi, proses pembentukan sikap, proses internalisasi atau pun proses pembentukan habit yang hanya dapat diketahui melalui suatu prosedur dan alat tertentu yang diyakini mewakili konstruk yang dimaksud.

Sejarah mencatat sejak tahun 1968 kurikulum mengalami perubahan sebanyak 6 kali, yakni kurikulum 1968, kurikulum 1975, kurikulum 1984, kurikulum 1994, kurikulum 2004 dan kurikulum 2006 kurikulum KTSP. Pembaharuan kurikulum dilakukan bukan berarti ganti menteri ganti kurikulum, namun disebabkan adanya perubahan dalam masyarakat, eksploitasi Ilmu Pengetahuan/Teknologi, Seni, Budaya dan lain-lain mengharuskan adanya perubahan kurikulum. ${ }^{10}$ Perubahan Kurikulum tersebut, merupakan salah satu inovasi dalam dunia pendidikan. Kurikulum berubah dikarenakan kurikulum mempunyai "kedudukan sentral" dalam proses pendidikan. ${ }^{11}$

Hal serupa disampaikan oleh Oliva dalam bukunya Developing the Curriculum, bahwa Kurikulum adalah perangkat pendidikan yang secara langsung mewakili pendidikan dalam menjawab tantangan masyarakat. ${ }^{12}$ Tantangan masyarakat tersebut dapat dikategorikan dalam berbagai jenjang seperti jenjang nasional, lokal, dan lingkungan terdekat (daerah). Tantangan tersebut tidak muncul begitu saja tetapi

${ }^{8}$ S. Nasution, Kurikulum dan Pembelajaran (Bandung: Jemmars, 2008), h. 17.

${ }^{9}$ P.F. Oliva, Developing the Curriculum, 4th ed. (Cet 1; New York: Longman, 2005), h. 54.

${ }^{10}$ Lihat, Nana Syaodih S., Prinsip dan Landasan Pengembangan Kurikulum, dalam Anik Ghufron, Fondasia: Majalah Ilmiah Fondasi Pendidikan, Volume 1 Nomor 9 (Maret, 2008), h. 4.

11 Nana Syaodih Sukmadinata, Pengembangan Kurikulum: Teori \& Praktik (Cet III; Bandung: Remaja Rosda Karya, 2008), 4.

${ }^{12}$ Lihat, P.F. Oliva, Developing the Curriculum, 4th ed, h. 60. 
direkonstruksi oleh sekelompok orang dan umumnya dilegalisasikan oleh pengambil keputusan.

Rekonstruksi tersebut menyangkut berbagai dimensi kehidupan dalam jenjangjenjang tersebut. Rekonstruksi itu memang sulit dan menjadi semakin sulit ketika dia harus merajut berbagai kepentingan yang berkenaan dengan berbagai jenjang dan dimensi kehidupan. Kesalahan yang umum terjadi adalah rekonstruksi tersebut terlalu fokus pada suatu jenjang, tingkat nasional misalnya, dan atau pada suatu dimensi seperti suatu disiplin ilmu tertentu. Kelemahan dalam rekonstruksi juga terjadi pada waktu menggunakan asumsi yang keliru untuk meproyeksi kebutuhan masyarakat di masa depan dan mendasarkan rekonstruksi pada asumsi tersebut.

Berdasarkan paparan di atas, maka kurikulum bisa dianggap sebagai jantungnya pendidikan. Artinya, aktivitas edukasi antara pendidik dengan peserta didik sangat dipengaruhi oleh muatan-muatan yang ada dalam krikulum. Sehingga dengan tidak adanya kurikulum seakan-akan kegiatan pendidikan tidak mungkin terjadi.

Mengingat pentingnya kedudukan kurikulum dalam pendidikan, maka pengembangan kurikulum juga sangat diperlukan. Pengembangan kurikulum pada dasarnya adalah proses penyusunan rencana tentang isi dan bahan pelajaran yang harus dipelajari serta bagaimana cara mempelajarinya. Menurut Wiles dan Bondi, pengembangan kurikulum adalah sebuah proses yang mengorganisir pembelajaran untuk mengambil tindakan sesuai dengan standar yang ditentukan. ${ }^{13}$

Seller dan Miller, sebagaimana dikutip oleh Oemar Hamalik, mengemukakan bahwa proses pengembangan kurikulum adalah rangkaian kegiatan yang dilakukan secara terus menerus. ${ }^{14}$ Dengan ini Seller memandang bahwa pengembangan kurikulum harus dimulai dari menentukan orientasi kurikulum, yakni kebijakan-kebijakan umum, misalnya arah dan tujuan pendidikan, pandangan tentang hakekat belajar dan hakekat anak didik, pandangan tentang keberhasilan implementasi kurikulum, dan lain sebagainya.

Berangkat dari orientasi tersebut, selanjutnya kurikulum dikembangkan menjadi pedoman pembelajaran, diimplementasikan dalam proses pembelajaran, dan akhirnya dievaluasi. Hasil evaluasi itulah yang kemudian dijadikan bahan dalam menentukan orientasi, begitu seterusnya, hingga membentuk siklus.

Orientasi pengembangan kurikulum menurut Seller dalam Oemar Hamalik menyangkut 6 aspek, yaitu:

1. Tujuan pendidikan menyangkut arah kegiatan pendidikan. Artinya, hendak dibawa kemana siswa yang kita didik itu.

13 Jon Wiles dan Joseph Bondi, Curriculum Development: A Guide to Practice (New Jersey: Pearson Education, Inc., 2002), h. 29.

${ }^{14}$ Oemar Hamalik, Manajemen Pengembangan Kurikulum (Cet.2; Bandung: Remaja Rosdakarya, 2006), h. 91. 
2. Pandangan tentang anak: apakah anak dianggap sebagai organisme yang aktif atau pasif.

3. Pandangan tentang proses pembelajaran: apakah proses pembelajaran itu dianggap sebagai proses transformasi ilmu pengetahuan atau mengubah perilaku anak.

4. Pandangan tentang lingkugan: apakah lingkungan belajar harus dikelola secara formal, atau secara bebas yang dapat memungkinkan anak bebas belajar.

5. Konsepsi tentang peranan guru: apakah guru harus berperan sebagai instruktur yang bersifat otoriter, atau guru dianggap sebagai fasilitator yang siap memberi bimbingan dan bantuan pada anak untuk belajar.

6. Evaluasi belajar: apakah mengukur keberhasilan dilakukan dengan tes atau non tes. $^{15}$

Mengacu pada proses pengembangan kurikulum sebagai siklus seperti yang dikemukakan Seller di atas, maka tampak bahwa pengembangan kurikulum pada hakikatnya adalah pengembangan komponen-komponen yang membentuk sistem kurikulum itu sendiri serta pengembangan komponen pembelajaran sebagai implementasi kurikulum. Dengan demikian, maka pengembangan kurikulum memiliki dua sisi yang sama pentingnya, yaitu sisi kurikulum sebagai pedoman yang kemudian membentuk kurikulum tertulis dan sisi kurikulum sebagai implementasi yang tidak lain adalah sistem pembelajaran.

Menurut Nana Sudjana, Pengembangan kurikulum merupakan tahap lanjutan dari pembinaan kurikulum, yakni usaha untuk meningkatkan dengan adanya nilai tambah dari apa yang telah dilaksanakan sesuai dengan kurikulum potensial. ${ }^{16}$ Usaha tersebut dilaksanakan setelah adanya evaluasi, sehingga dapat diketahui kekurangan dari aspek pelaksanaan dan pembinaan kurikulum. Dengan mengetahi kekurangan tersebut, pengembang kurikulum segera mencarikan solusi dan mengambil alternatif lain yang lebih baik, dengan tujuan pelaksanaan dan pembinaan kurikulum dari tahun ke tahun terus meningkat sehingga ada nilai tambah. Siklus aktivitas seperti itu kemudian disebut sebagai pengembangan kurikulum.

Proses pengembangan kurikulum menurut Zais dalam Nana Sudjana, harus dimulai dengan meletakkan dasar dalam pengembangan kurikulum, yakni asumsiasumsi filosofis sebagai sistem nilai (value system) atau pandangan hidup suatu bangsa. Berdasarkan asas filosofis tersebut kemudian menentukan hakikat pengetahuan, sosiokultural, hakikat anak didik, dan teori-teori belajar. dengan kata lain, landasan pengembangan kuriklum itu meliputi asas filosofis, asas psikologis, asas sosial budaya, dan asas teknologis. ${ }^{17}$

Setelah menentukan landasan-landasan sebagai fondasi kurikulum, pada tahap

\footnotetext{
${ }^{15}$ Oemar Hamalik, Manajemen Pengembangan Kurikulum, h. 91.

${ }^{16}$ Nana Sudjana, Pembinaan dan Pengembangan Kurikulum di Sekolah, h. 9.

${ }^{17}$ Nana Sudjana, Pembinaan dan Pengembangan Kurikulum di Sekolah, h. 36
} 
selanjutnya, menentukan komponen-komponen kurikulum yang menyangkut tujuan, baik tujuan umum maupun tujuan khusus, isi atau materi pelajaran, kegiatan pembelajaran, dan evaluasi. Jadi, pada dasarnya proses pengembangan kurikulum adalah proses penyusunan keempat komponen tersebut yang dilandasi oleh asas-asas pengembangannya sebagai fondasi.

\section{PENUTUP}

\section{Kesimpulan}

1. Landasan sosial budaya dan perkembangan ilmu pengetahuan dalam pengembangan kurikulum, yaitu dimana pengembangan kurikulum hendaknya memperhatikan kebutuhan masyarakat dan perkembangan masyarakat baik dari segi penerapan teori, prinsip, hukum, dan konsep-konsep yang terdapat dalam semua ilmu pengetahuan yang ada dalam kurikulum, harus disesuaikan dengan kondisi sosial budaya masyarakat setempat, sehingga hasil belajar yang dicapai oleh siswa lebih bermakna dalam hidupnya.

2. Komponen dan kedudukan Kurikulum, yaitu dimana komponen kurikulum antara lain: Knowledge (pengetahuan), informasi-informasi, data-data, aktivitas-aktivitas dan pengalaman-pengalaman yang menjadikan kurikulum itu terbentuk, metode dan cara-cara mengajar dan metode dan cara penilaian. Sedangkan kurikulum memiliki kedudukan dimana kurikulum dianggap sebagai jantungnya pendidikan. Artinya, aktivitas edukasi antara pendidik dengan peserta didik sangat dipengaruhi oleh muatan-muatan yang ada dalam krikulum. Sehingga dengan tidak adanya kurikulum seakan-akan kegiatan pendidikan tidak mungkin terjadi. Urgensitas pengembangan kurikulum, yaitu dimana kurikulum memiliki dua sisi yang sama pentingnya, yaitu sisi kurikulum sebagai pedoman yang kemudian membentuk kurikulum tertulis dan sisi kurikulum sebagai implementasi yang tidak lain adalah sistem pembelajaran.

\section{DAFTAR PUSTAKA}

Bondi, Joseph dan Jon Wiles. Curriculum Development: A Guide to Practice, New Jersey: Pearson Education, Inc., 2002.

Hamalik, Oemar. Manajemen Pengembangan Kurikulum, Cet.2; Bandung: Remaja Rosdakarya, 2006

Idi , Abdullah. Pengembangan Kurikulum, teori \& praktek, Cet. 1; Yogyakarta, arr ruzz media, 2007.

Langgulung, Hasan. Asas-Asas Pendidikan Islam, Cet. XVII; Jakarta: Pustaka AlHusna, 2010. 
Lihat, Syaodih S, Nana. Prinsip dan Landasan Pengembangan Kurikulum, dalam Anik Ghufron, Fondasia: Majalah Ilmiah Fondasi Pendidikan, Volume 1 Nomor 9 (Maret, 2008),

Purwanto, Ngalim. Ilmu Pendidikan, Teoritis dan praktis, Cet 3; Bandung;Rosdakarya, 2008.

P.F. Oliva, Developing the Curriculum, 4th ed. Cet 1; New York: Longman, 2005.

S. Nasution, Kurikulum dan Pembelajaran, Bandung: Jemmars, 2008.

Sudjana, Nana Pembinaan dan Pengembangan Kurikulum di Sekolah, Cet III; Bandung: Sinar Baru Algensindo, 2008.

Sukmadinata, Nana Syaodih Pengembangan Kurikulum: Teori \& Praktik, Cet III; Bandung: Remaja Rosda Karya, 2008. 